\title{
The Effects of Temperature and Relative Humidity on the Viability of the SARS Coronavirus
}

\author{
K. H. Chan, J. S. Malik Peiris, S. Y. Lam, L. L. M. Poon, K. Y. Yuen, and W. H. Seto \\ Department of Microbiology, The University of Hong Kong, Queen Mary Hospital, Pokfulam, Hong Kong \\ Correspondence should be addressed to K. H. Chan, chankh2@hkucc.hku.hk
}

Received 25 November 2010; Revised 31 July 2011; Accepted 31 July 2011

Academic Editor: Alain Kohl

Copyright ( $) 2011$ K. H. Chan et al. This is an open access article distributed under the Creative Commons Attribution License, which permits unrestricted use, distribution, and reproduction in any medium, provided the original work is properly cited.

The main route of transmission of SARS CoV infection is presumed to be respiratory droplets. However the virus is also detectable in other body fluids and excreta. The stability of the virus at different temperatures and relative humidity on smooth surfaces were studied. The dried virus on smooth surfaces retained its viability for over 5 days at temperatures of $22-25^{\circ} \mathrm{C}$ and relative humidity of $40-50 \%$, that is, typical air-conditioned environments. However, virus viability was rapidly $\operatorname{lost}_{(}\left(>3 \log _{10}\right)$ at higher temperatures and higher relative humidity (e.g., $38^{\circ} \mathrm{C}$, and relative humidity of $>95 \%$ ). The better stability of SARS coronavirus at low temperature and low humidity environment may facilitate its transmission in community in subtropical area (such as Hong Kong) during the spring and in air-conditioned environments. It may also explain why some Asian countries in tropical area (such as Malaysia, Indonesia or Thailand) with high temperature and high relative humidity environment did not have major community outbreaks of SARS.

\section{Introduction}

Severe acute respiratory syndrome (SARS), was a new emerging disease associated with severe pneumonia and spread to involve over 30 countries in 5 continents in 2003. A novel coronavirus was identified as its cause [1-3]. SARS had a dramatic impact on health care services and economies of affected countries, and the overall mortality rate was estimated to be $9 \%$, but rising to $50 \%$ in those aged 60 or above [4]. A notable feature of this disease was its predilection for transmission in the health care setting and to close family and social contacts. The disease is presumed to be spread by droplets, close direct or indirect contact, but the relative importance of these routes of transmission is presently unclear. A study showed that viral aerosol generation by a patient with SARS was possible and therefore airborne droplet transmission was a possible means of transmission [5]. However, the role of fomites and environmental contamination in transmission of infection is presently still unclear. An outbreak of disease affecting over 300 residents in high-rise apartment block (Amoy Gardens) in Hong Kong could not be explained by respiratory droplet transmission from infected patients [6]. Infectious virus is detectable in the faeces [7], and aerosolization of virus in contaminated faeces is believed to be the mode of transmission of this outbreak [8].

We and others have reported that infectivity of SARS CoV (SARS coronavirus) was lost after heating at $56^{\circ} \mathrm{C}$ for 15 minutes but that it was stable for at least 2 days following drying on plastic. It was completely inactivated by common fixatives used in laboratory $[9,10]$. Another study showed that it was inactivated by ultraviolet light, alkaline $(\mathrm{pH}>12)$, or acidic $(\mathrm{pH}<3)$ conditions [11]. Human coronaviruses have been shown to survive in PBS or culture medium with 5-10\% FCS for several days [12-14] but they only survive a few hours after drying $[13,14]$. There have been some studies reporting an association between the SARS outbreak, metrological factors, and air pollution [15-17]. Thus, information on the survival of the SARS coronavirus (SCoV) in the environment at different temperature and humidity conditions is of significant interest to understanding virus transmission. A recent study using surrogate coronaviruses (transmissible gastroenteritis virus (TGEV) and mouse hepatitis virus (MHC)) has investigated the effect of air 
TABLE 1: WHO SARS report—based on data as of the 31st December 2003.

\begin{tabular}{|c|c|c|c|c|c|c|c|c|}
\hline Areas & Total & Medan age & Deaths & Case fatality Ratio (\%) & No. of imported Cases (\%) & No. of HCW (\%) & First case & Last case \\
\hline China & 5327 & NKn & 349 & 7 & NA & $1002(19)$ & Nov-02 & Jun-03 \\
\hline Hong Kong & 1755 & 40 & 299 & 17 & NA & $386(22)$ & Feb-03 & May-03 \\
\hline Taiwan & 346 & 42 & 37 & 11 & $21(6)$ & $68(20)$ & Feb-03 & Jun-03 \\
\hline Singapore & 238 & 35 & 33 & 14 & $8(3)$ & $97(41)$ & Feb-03 & May-03 \\
\hline Viet Nam & 63 & 43 & 5 & 8 & $1(2)$ & $36(57)$ & Feb-03 & Apr-03 \\
\hline Indonesia & 2 & 56 & 0 & 0 & $2(100)$ & $0(0)$ & Apr-03 & Apr-03 \\
\hline Malaysia & 5 & 30 & 2 & 40 & $5(100)$ & $0(0)$ & Mar-03 & Apr-03 \\
\hline Thailand & 9 & 42 & 2 & 22 & $9(100)$ & $1(11)$ & Mar-03 & May-03 \\
\hline Philippines & 14 & 41 & 2 & 14 & $7(50)$ & $4(29)$ & Feb-03 & May-03 \\
\hline Total & 8096 & & 774 & 9.6 & 142 & $1706(21)$ & & \\
\hline
\end{tabular}

temperature and relative humidity on coronavirus survival on surface [18]. The survival effects of these environmental factors on SARS coronavirus remain unclear. In the present study, we report the stability of the SARS coronavirus at different temperatures and relative humidity.

\section{Material and Methods}

2.1. Virus Strain and Cell Line. The SARS CoV strain used in this study is HKU39849. Foetal monkey kidney cells (FRhK4) were cultured in minimal essential medium (MEM, Gibco, USA) with $10 \%$ foetal calf serum and penicillin streptomycin (Gibco, USA) at $37^{\circ} \mathrm{C}$ in $5 \% \mathrm{CO}_{2}$ and were used for growing stock virus and for titration of viral infectivity $[1,2]$.

2.2. Preparation of Stock Virus. Stock virus was harvested when infection approximately $75 \%$ of the cell monolayer of a virus infected flask manifested cytopathic effect (CPE). Infected cells were subjected to one cycle of freeze and thaw centrifuged at $2000 \mathrm{rpm}$ for 20 minutes to remove cell debris and the culture supernatant was aliquoted and stored at $-80^{\circ} \mathrm{C}$ until use.

2.3. Determination of Tissue Culture Infectious Dose (50\%) $\left(T_{C I D}\right)$. 96-well microtitre plates containing $100 \mu \mathrm{L}$ of confluent FRhK-4 were infected with $100 \mu \mathrm{L}$ of serial 10 fold of dilutions of stock virus in minimal essential medium with $1 \%$ FCS (maintenance medium) starting from $10^{-1}$ to $10^{8}$. Titrations were done in quadruplicate. Infected cells were incubated for 4 days at $37^{\circ} \mathrm{C}$. Appearance of CPE was recorded daily. TCID $_{50}$ was determined according to Reed and the Muench method [19].

2.4. Effect of Drying, Heat, and Relative Humidity. Ten microlitre of maintenance medium containing $10^{7} \mathrm{TCID}_{50}$ per $\mathrm{mL}$ of virus was placed in individual wells of a 24well plastic plates and allowed to dry at room temperature $\left(22 \sim 25^{\circ} \mathrm{C}\right)$ and relative humidity of $40-50 \%$ (i.e., conditions prevailing in a typical air-conditioned room). One hundred microlitre of MM was used to resuspend the virus at $0 \mathrm{hr}$, $3 \mathrm{hr}, 7 \mathrm{hr}, 11 \mathrm{hr}, 13 \mathrm{hr}, 24 \mathrm{hr}$, and up to 4 weeks and the residual virus infectivity was titrated. Controls in closed screw cap eppendorf tube were included each time and treated similarly but without drying.

The experiment was repeated at different temperatures $\left(38^{\circ} \mathrm{C}, 33^{\circ} \mathrm{C}, 28^{\circ} \mathrm{C}\right)$ and relative humidities (>95\%, 80 89\%) for $3 \mathrm{hr}, 7 \mathrm{hr}, 11 \mathrm{hr}, 13 \mathrm{hr}$, and $24 \mathrm{hr}$. A nebulizer under a controlled condition was used to generate high and relative low humidity environment. All the experiments above were conducted in duplicate and the residual viral infectivity was titrated.

2.5. Infectivity Assay. The infectivity of residual virus was titrated in quadruplicate on 96-well microtitre plates containing $100 \mu \mathrm{L}$ of confluent FRhK-4 cells. $100 \mu \mathrm{L}$ of serial $10-$ fold of dilutions of virus in maintenance medium starting from $10^{-1}$ to $10^{8}$ was added into FRhK-4 cells. The infected cells were incubated at $37^{\circ} \mathrm{C}$ for 4 days. Appearance of $\mathrm{CPE}$ was recorded daily. $\mathrm{TCID}_{50}$ was determined according to the Reed and Muench method [19].

\section{Results}

Ten microlitre of $10^{7} \mathrm{TCID}_{50}$ per $\mathrm{mL}$ of virus was placed in individual wells of a 24 -well plastic plate (representing a nonporous surface) and dried. The dried virus was then incubated at different temperatures $\left(38^{\circ} \mathrm{C}, 33^{\circ} \mathrm{C}, 28^{\circ} \mathrm{C}\right)$ at different relative humidity ( $>95 \%, 80 \sim 89 \%$ ) for $3 \mathrm{hr}, 7 \mathrm{hr}$, $11 \mathrm{hr}, 13 \mathrm{hr}$, and $24 \mathrm{hr}$ and the residual viral infectivity was titrated. A similar experiment was conducted at room temperature and relative humidity of about $40-50 \%$ (airconditioned room) for up to 4 weeks. Virus dried on plastic retained viability for up to 5 days at $22 \sim 25^{\circ} \mathrm{C}$ at relative humidity of $40 \sim 50 \%$ with only $1 \log _{10}$ loss of titre (Figure 1 ). After that virus infectivity is gradually lost ever time. Loss of virus infectivity in solution was generally similar to dried virus under these environmental conditions. This indicates that SARS CoV is a stable virus that may potentially be transmitted by indirect contact or fomites, especially in airconditioned environments.

High relative humidity $(>95 \%)$ at comparatively low temperature $\left(28^{\circ} \mathrm{C}\right.$ and $\left.33^{\circ} \mathrm{C}\right)$ did not affect the virus infectivity significantly (Figure $2(\mathrm{a})$ ). High temperature $\left(38^{\circ} \mathrm{C}\right)$ at $80-90 \%$ relative humidity led to a $0.25 \sim 2 \log _{10} \operatorname{loss}_{\text {of titre at }}$ $24 \mathrm{hr}$ (Figure 2(b)). However, if the dried virus was stored at 


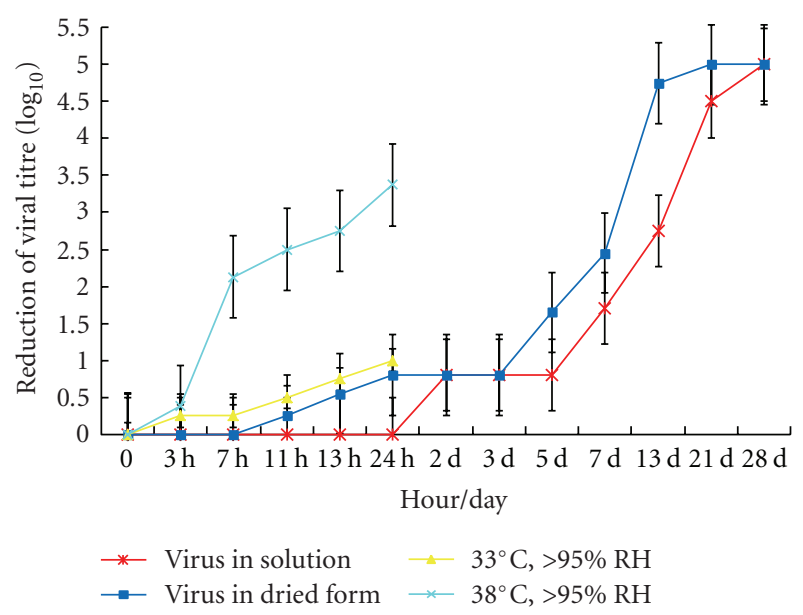

FIgURE 1: Residual virus infectivity at $22-25^{\circ} \mathrm{C}$ with relative humidity $40-50 \%$ (starting titre $10^{5} / 10 \mu \mathrm{L}$ ) and at $33^{\circ} \mathrm{C}$ or $38^{\circ} \mathrm{C}$ with relative humidity $>95 \%$.

high temperature $\left(38^{\circ} \mathrm{C}\right)$ and high relative humidity $(>95 \%)$, there was a further $\sim 1.5 \log$ loss of titre for each time point up to $24 \mathrm{hr}\left(0.38 \sim 3.38 \log _{10}\right)$ when compared with high temperature $\left(38^{\circ} \mathrm{C}\right)$ at a lower relative humidity $80-90 \%$ (Figures 3(a)-3(c)).

\section{Discussion}

Viruses do not replicate outside living cell but infectious virus may persist on contaminated environmental surfaces and the duration of persistence of viable virus is affected markedly by temperature and humidity. Contaminated surfaces are known to be significant vectors in the transmission of infections in the hospital setting as well as the community. The role of fomites in the transmission of RSV has been clearly demonstrated [20]. Survival of viruses on a variety of fomites has been studied for influenza viruses, paramyxoviruses, poxviruses, and retroviruses [21]. The human coronavirus associated with the common cold was reported to remain viable only for 3 hours on environmental surfaces after drying, although it remains viable for many days in liquid suspension [13]. Parainfluenza and RSV viruses were viable after drying on surfaces for 2 and 6 hours, respectively $[20,22]$. In aerosolised form, human coronavirus $229 \mathrm{E}$ is generally less stable in high humidity [12]. The environmental stability of SCoV was previously unknown and this information is clearly important for understanding the mechanisms of transmission of this virus in a hospital and community setting.

In the present study, we have demonstrated that SARS $\mathrm{CoV}$ can survive at least two weeks after drying at temperature and humidity conditions found in an air-conditioned environment. The virus is stable for 3 weeks at room temperature in a liquid environment but it is easily killed by heat at $56^{\circ} \mathrm{C}$ for 15 minutes [9]. This indicates that SARS $\mathrm{CoV}$ is a stable virus that may potentially be transmitted by indirect contact or fomites. These results may indicate that contaminated surfaces may play a major role in transmission of infection in the hospital and the community.

Our studies indicate that $\mathrm{SCoV}$ is relatively more stable than the human coronaviruses $229 \mathrm{E}$ or OC43 and some other viral respiratory pathogens such as respiratory syncytial virus. These findings suggest that, while direct droplet transmission is an important route of transmission [23], the role of fomites and environmental contamination in virus transmission may play a significant role in virus transmission. In particular, fomites may contribute to the continued transmission of infection in the nosocomial setting that continues to occur in spite of the great attention and stringent precautions taken to prevent droplet spread. In addition to droplet precautions, reenforcing contact precautions and hand washing is called for.

Faecal contamination of SCoV coronavirus may thus be an effective route of transmission of the disease. The outbreak in Amoy Garden in Hong Kong which affected over 300 residents in a single-apartment block with thought to have been transmitted by contaminated sewage. The stability of the virus on environmental surfaces and its presence in faeces indicates the potential that fecal contamination of fresh-food production may pose a threat for virus transmission; especially in countries with poor sanitation and sewage disposal systems and that studies to address this possibility are needed.

In this study, we showed that high temperature at high relative humidity has a synergistic effect on inactivation of SARS CoV viability while lower temperatures and low humidity support prolonged survival of virus on contaminated surfaces. The environmental conditions of countries such as Malaysia, Indonesia, and Thailand are thus not conducive to the prolonged survival of the virus. In countries such as Singapore and Hong Kong where there is a intensive use of air-conditioning, transmission largely occurred in well-air-conditioned environments such as hospitals or hotels. Further, a separate study has shown that during the epidemic, the risk of increased daily incidence of SARS was 18.18-fold higher in days with a lower air temperature than in days with a higher temperature in Hong Kong [24] and other regions [15-17]. Taken together, these observations may explain why some Asian countries in tropical area (with high temperature at high relative humidity) such as Malaysia, Indonesia, and Thailand did not have nosocomial outbreaks of SARS (Tables 1 and 2(a)-2(c)). It may also explain why Singapore, which is also in tropical area (Table 2(d)), had most of its SARS outbreaks in hospitals (air-conditioned environment). Interestingly, during the outbreak of SARS in Guangzhou, clinicians kept the windows of patient rooms open and well ventilated and these may well have reduced virus survival and this reduced nosocomial transmission. SARS $\mathrm{CoV}$ can retain its infectivity up to 2 weeks at low temperature and low humidity environment, which might facilitate the virus transmission in community as in Hong Kong which locates in subtropical area (Table 2(e)). Other environmental factors including wind velocity, daily sunlight, and air pressure, had shown to be associated with SARS epidemic, should also be considered [16, 17]. The dynamics of SARS epidemic involves multiple factors 

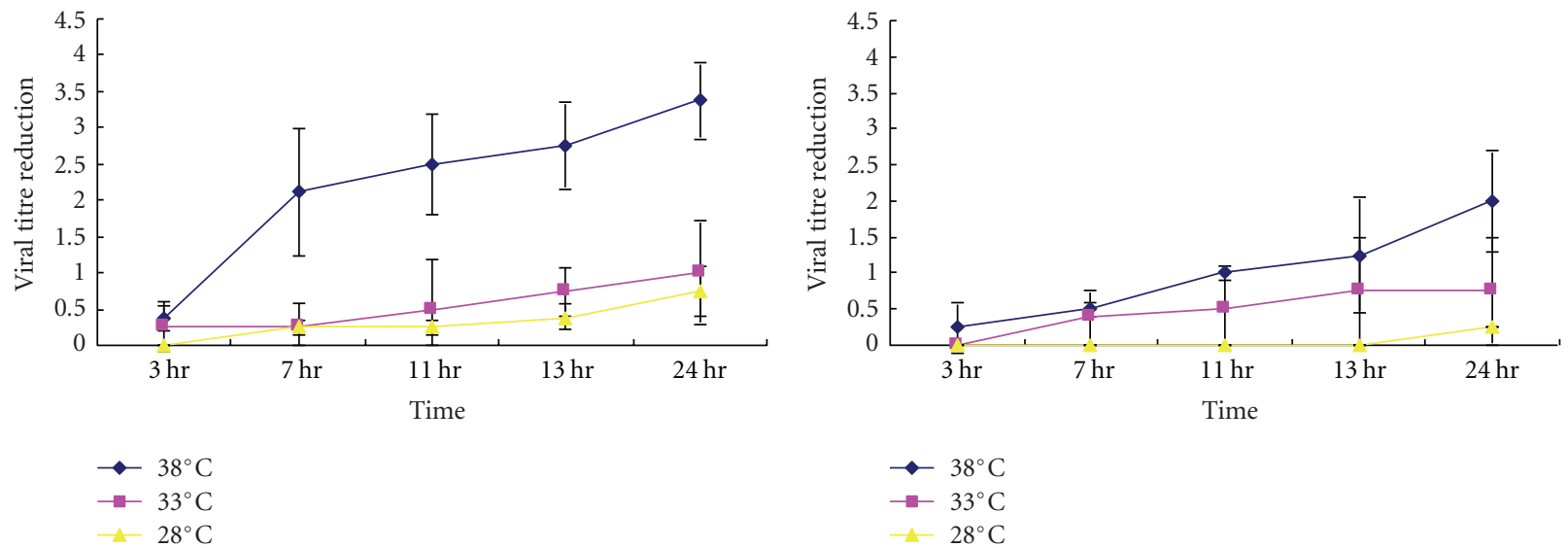

(a)

(b)

FIGURE 2: Infectivity of SARS Coronavirus $\left(10^{5} / 10 \mu \mathrm{L}\right.$ ) to different temperatures at (a) $>95 \%$ relative humidity, (b) $>80-89 \%$.

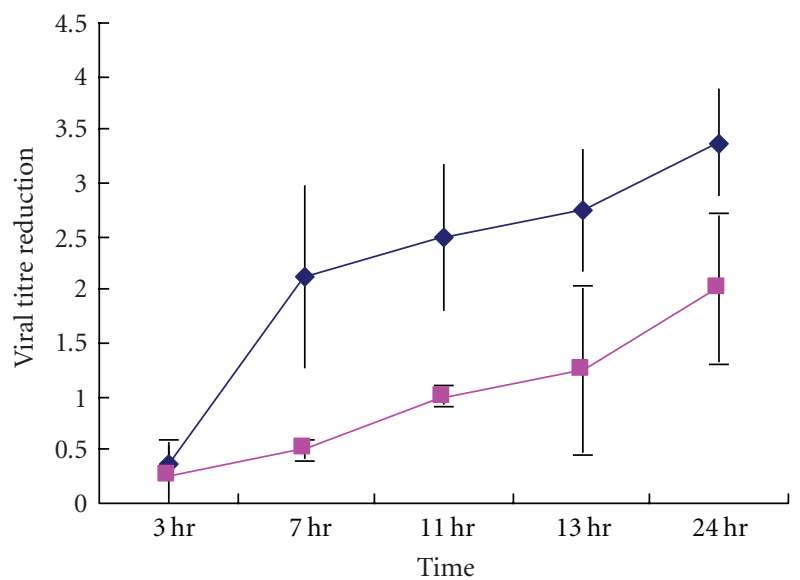

(a)

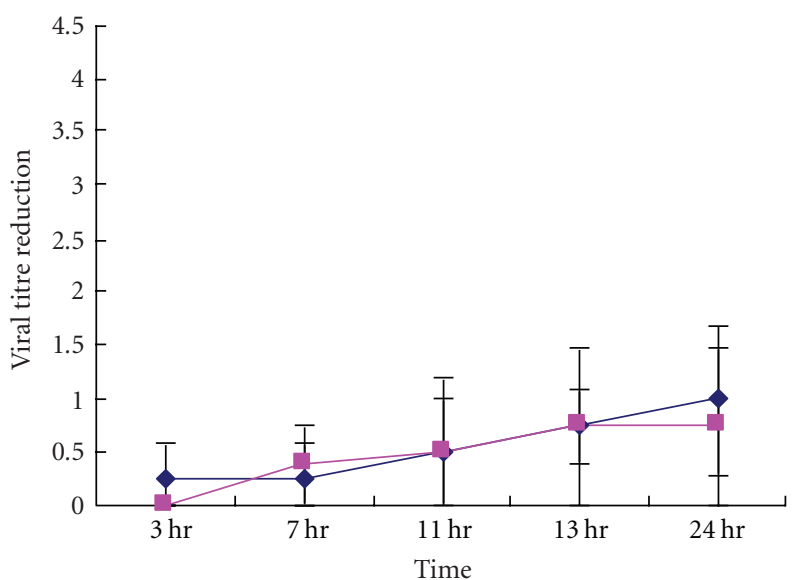

(b)

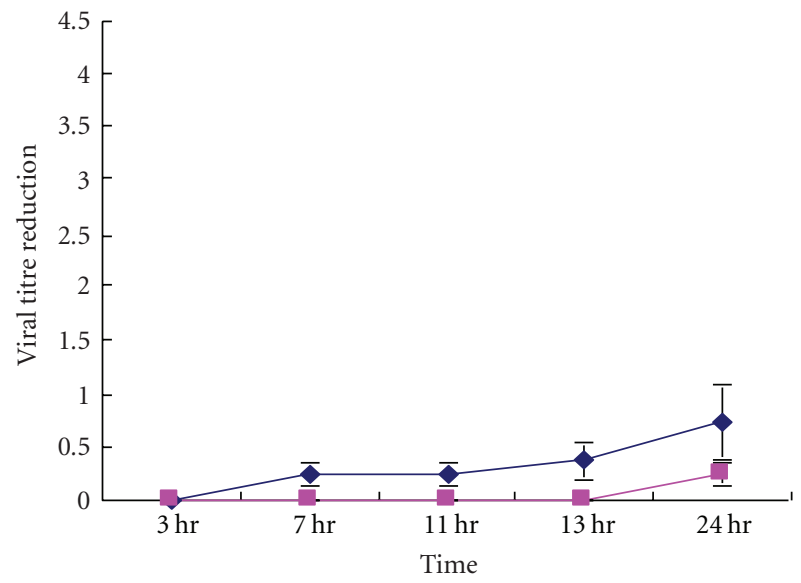

$\neg>95 \% \mathrm{RH}$

- $80-85 \% \mathrm{RH}$

(c)

FIGURE 3: Infectivity of SARS Coronavirus (starting titre $10^{5} / 10 \mu \mathrm{L}$ ) at different relative humidity at (a) $38^{\circ} \mathrm{C}$, (b) $33^{\circ} \mathrm{C}$, and (c) $28^{\circ} \mathrm{C}$. 
TABLE 2: A summary of the meteorological data of 2005 in average weather conditions*.

\begin{tabular}{|c|c|c|c|c|c|c|}
\hline \multirow{2}{*}{ Month } & \multirow{2}{*}{ Average sunlight (hours) } & \multicolumn{2}{|c|}{ Temperature } & \multirow{2}{*}{ Discomfort from heat and humidity } & \multicolumn{2}{|c|}{ Relative humidity } \\
\hline & & Min & Max & & am & $\mathrm{pm}$ \\
\hline \multicolumn{7}{|c|}{ (a) Kuala Lumpur, Malaysia } \\
\hline Jan & 6 & 22 & 32 & High & 97 & 60 \\
\hline Feb & 7 & 22 & 33 & High & 97 & 60 \\
\hline March & 7 & 23 & 33 & High & 97 & 58 \\
\hline April & 6 & 23 & 33 & High & 97 & 63 \\
\hline May & 6 & 23 & 33 & High & 97 & 66 \\
\hline June & 7 & 22 & 33 & High & 96 & 63 \\
\hline July & 7 & 23 & 32 & High & 95 & 63 \\
\hline Aug & 6 & 23 & 32 & High & 96 & 62 \\
\hline Sept & 6 & 23 & 32 & High & 96 & 64 \\
\hline Oct & 5 & 23 & 32 & High & 96 & 65 \\
\hline Nov & 5 & 23 & 32 & High & 97 & 66 \\
\hline Dec & 5 & 22 & 32 & High & 97 & 61 \\
\hline \multicolumn{7}{|c|}{ (b) Jakarta, Indonesia } \\
\hline Jan & 5 & 23 & 29 & High & 95 & 75 \\
\hline Feb & 5 & 23 & 29 & High & 95 & 75 \\
\hline March & 6 & 23 & 30 & High & 94 & 73 \\
\hline April & 7 & 24 & 31 & High & 94 & 71 \\
\hline May & 7 & 24 & 31 & High & 94 & 69 \\
\hline June & 7 & 23 & 31 & High & 93 & 67 \\
\hline July & 7 & 23 & 31 & High & 92 & 64 \\
\hline Aug & 8 & 23 & 31 & High & 90 & 61 \\
\hline Sept & 8 & 23 & 31 & High & 90 & 62 \\
\hline Oct & 7 & 23 & 31 & High & 90 & 64 \\
\hline Nov & 6 & 23 & 30 & High & 92 & 68 \\
\hline Dec & 5 & 23 & 29 & High & 92 & 71 \\
\hline \multicolumn{7}{|c|}{ (c) Bangkok, Thailand } \\
\hline Jan & 9 & 20 & 32 & High & 91 & 53 \\
\hline Feb & 8 & 22 & 33 & High & 92 & 55 \\
\hline March & 9 & 24 & 34 & High & 92 & 56 \\
\hline April & 8 & 25 & 35 & Extreme & 90 & 58 \\
\hline May & 8 & 25 & 34 & Extreme & 91 & 64 \\
\hline June & 6 & 24 & 33 & Extreme & 90 & 67 \\
\hline July & 5 & 24 & 32 & High & 91 & 66 \\
\hline Aug & 5 & 24 & 32 & High & 92 & 66 \\
\hline Sept & 5 & 24 & 32 & High & 94 & 70 \\
\hline Oct & 6 & 24 & 31 & High & 93 & 70 \\
\hline Nov & 8 & 22 & 31 & High & 92 & 65 \\
\hline Dec & 9 & 20 & 31 & High & 91 & 56 \\
\hline \multicolumn{7}{|c|}{ (d) Singapore } \\
\hline Jan & 5 & 23 & 30 & High & 82 & 78 \\
\hline $\mathrm{Feb}$ & 7 & 23 & 31 & High & 77 & 71 \\
\hline March & 6 & 24 & 31 & High & 76 & 70 \\
\hline April & 6 & 24 & 31 & High & 77 & 74 \\
\hline May & 6 & 24 & 32 & Extreme & 79 & 73 \\
\hline June & 6 & 24 & 31 & High & 79 & 73 \\
\hline July & 6 & 24 & 31 & High & 79 & 72 \\
\hline Aug & 6 & 24 & 31 & High & 78 & 72 \\
\hline Sept & 5 & 24 & 31 & High & 79 & 72 \\
\hline Oct & 5 & 23 & 31 & High & 78 & 72 \\
\hline Nov & 5 & 23 & 31 & High & 79 & 75 \\
\hline Dec & 4 & 23 & 31 & High & 82 & 78 \\
\hline
\end{tabular}


TABle 2: Continued.

\begin{tabular}{|c|c|c|c|c|c|c|}
\hline \multirow{2}{*}{ Month } & \multirow{2}{*}{ Average sunlight (hours) } & \multicolumn{2}{|c|}{ Temperature } & \multirow{2}{*}{ Discomfort from heat and humidity } & \multicolumn{2}{|c|}{ Relative humidity } \\
\hline & & Min & Max & & $\mathrm{am}$ & $\mathrm{pm}$ \\
\hline \multicolumn{7}{|c|}{ (e) Hong Kong } \\
\hline Jan & 5 & 13 & 18 & - & 77 & 66 \\
\hline Feb & 4 & 13 & 17 & - & 82 & 73 \\
\hline March & 3 & 16 & 19 & - & 84 & 74 \\
\hline April & 4 & 19 & 24 & Medium & 87 & 77 \\
\hline May & 5 & 23 & 28 & Medium & 87 & 78 \\
\hline June & 5 & 26 & 29 & High & 86 & 77 \\
\hline July & 8 & 26 & 31 & High & 87 & 77 \\
\hline Aug & 6 & 26 & 31 & High & 87 & 77 \\
\hline Sept & 6 & 25 & 29 & High & 83 & 72 \\
\hline Oct & 7 & 23 & 27 & Medium & 75 & 63 \\
\hline Nov & 7 & 18 & 23 & Moderate & 73 & 60 \\
\hline Dec & 6 & 15 & 20 & - & 74 & 63 \\
\hline
\end{tabular}

${ }^{*}$ Data is available at BBC weather website (http://www.bbc.co.uk/weather/world/city_guides/results).

including physical property of virus, outdoor and indoor environments, hygiene, space, and genetic predispositions $[10,15-17,24,25]$. Understanding the stability of viruses in different temperature and humidity conditions is important in understanding transmission of novel infectious agent including that of the recent influenza Apandemic H1N12009.

\section{Conflict of Interests}

The authors declare that there is no conflict of interest.

\section{References}

[1] J. S. M. Peiris, S. T. Lai, L. L. M. Poon et al., "Coronavirus as a possible cause of severe acute respiratory syndrome," The Lancet, vol. 361, no. 9366, pp. 1319-1325, 2003.

[2] T. G. Ksiazek, D. Erdman, C. S. Goldsmith et al., "A novel coronavirus associated with severe acute respiratory syndrome," New England Journal of Medicine, vol. 348, no. 20, pp. 1953-1966, 2003.

[3] C. Drosten, S. Günther, W. Preiser et al., "Identification of a novel coronavirus in patients with severe acute respiratory syndrome," New England Journal of Medicine, vol. 348, no. 20, pp. 1967-1976, 2003.

[4] C. A. Donnelly, A. C. Ghani, G. M. Leung et al., "Epidemiological determinants of spread of causal agent of severe acute respiratory syndrome in Hong Kong," The Lancet, vol. 361, no. 9371, pp. 1761-1766, 2003.

[5] T. F. Booth, B. Kournikakis, N. Bastien et al., "Detection of airborne severe acute respiratory syndrome (SARS) coronavirus and environmental contamination in SARS outbreak units," Journal of Infectious Diseases, vol. 191, no. 9, pp. 1472-1477, 2005.

[6] Department of Health, "Outbreak of sever acute respiratory syndrome (SARS) at Amoy Gardens, Kowloon Bay, Hong Kong main findings of the investigation," 2003.

[7] J. S. M. Peiris, C. M. Chu, V. C. C. Cheng et al., "Clinical progression and viral load in a community outbreak of coronavirus-associated SARS pneumonia: a prospective study," The Lancet, vol. 361, no. 9371, pp. 1767-1772, 2003.
[8] I. T. S. Yu, Y. Li, T. W. Wong et al., "Evidence of airborne transmission of the severe acute respiratory syndrome virus," New England Journal of Medicine, vol. 350, no. 17, pp. 17311739, 2004.

[9] WHO Report, "First data on stability and resistance of SARS coronavirus compiled by members of WHO laboratory network," http:www.who.int/csr/sars/survival_2003_05_04/en/\#.

[10] M. Y. Lai, P. K. Cheng, and W. W. Lim, "Survival of severe acute respiratory syndrome coronavirus," Clinical Infectious Diseases, vol. 41, no. 7, pp. e67-e71, 2005.

[11] M. E. R. Darnell, K. Subbarao, S. M. Feinstone, and D. R. Taylor, "Inactivation of the coronavirus that induces severe acute respiratory syndrome, SARS-CoV," Journal of Virological Methods, vol. 121, no. 1, pp. 85-91, 2004.

[12] M. K. Ijaz, A. H. Brunner, and S. A. Sattar, "Survival characteristics of airborne human coronavirus 229E," Journal of General Virology, vol. 66, no. 12, pp. 2743-2748, 1985.

[13] J. Sizun, M. W. N. Yu, and P. J. Talbot, "Survival of human coronaviruses 229E and OC43 in suspension and after drying on surfaces: a possible source of hospital-acquired infections," Journal of Hospital Infection, vol. 46, no. 1, pp. 55-60, 2000.

[14] H. F. Rabenau, J. Cinatl, B. Morgenstern, G. Bauer, W. Preiser, and H. W. Doerr, "Stability and inactivation of SARS coronavirus," Medical Microbiology and Immunology, vol. 194, no. 1-2, pp. 1-6, 2005.

[15] J. Tan, L. Mu, J. Huang, S. Yu, B. Chen, and J. Yin, “An initial investigation of the association between the SARS outbreak and weather: with the view of the environmental temperature and its variation," Journal of Epidemiology and Community Health, vol. 59, no. 3, pp. 186-192, 2005.

[16] J. Yuan, H. Yun, W. Lan et al., "A climatologic investigation of the SARS-CoV outbreak in Beijing, China," American Journal of Infection Control, vol. 34, no. 4, pp. 234-236, 2006.

[17] Q. C. Cai, J. Lu, Q. F. Xu et al., "Influence of meteorological factors and air pollution on the outbreak of severe acute respiratory syndrome," Public Health, vol. 121, no. 4, pp. 258265, 2007.

[18] L. M. Casanova, S. Jeon, W. A. Rutala, D. J. Weber, and M. D. Sobsey, "Effects of air temperature and relative humidity on coronavirus survival on surfaces," Applied and Environmental Microbiology, vol. 76, no. 9, pp. 2712-2717, 2010. 
[19] L. J. Reed and H. Muench, "A simple method of estimating fifty per cent endpoints," American Journal of Epidemiology, vol. 27, no. 3, pp. 493-497, 1938.

[20] C. B. Hall, R. G. Douglas, and J. M. Geiman, "Possible transmission by fomites of respiratory syncytial virus," Journal of Infectious Diseases, vol. 141, no. 1, pp. 98-102, 1980.

[21] E. C. Pirtle and G. W. Beran, "Virus survival in the environment," OIE Revue Scientifique et Technique, vol. 10, no. 3, pp. 733-748, 1991.

[22] M. T. Brady, J. Evans, and J. Cuartas, "Survival and disinfection of parainfluenza viruses on environmental surfaces," American Journal of Infection Control, vol. 18, no. 1, pp. 18-23, 1990.

[23] W. H. Seto, D. Tsang, R. W. H. Yung et al., "Effectiveness of precautions against droplets and contact in prevention of nosocomial transmission of severe acute respiratory syndrome (SARS)," The Lancet, vol. 361, no. 9368, pp. 1519-1520, 2003.

[24] K. Lin, D. Y. K. Fong, B. Zhu, and J. Karlberg, "Environmental factors on the SARS epidemic: air temperature, passage of time and multiplicative effect of hospital infection," Epidemiology and Infection, vol. 134, no. 2, pp. 223-230, 2006.

[25] V. S. F. Chan, K. Y. K. Chan, Y. Chen et al., "Homozygous LSIGN (CLEC4M) plays a protective role in SARS coronavirus infection," Nature Genetics, vol. 38, no. 1, pp. 38-46, 2006. 

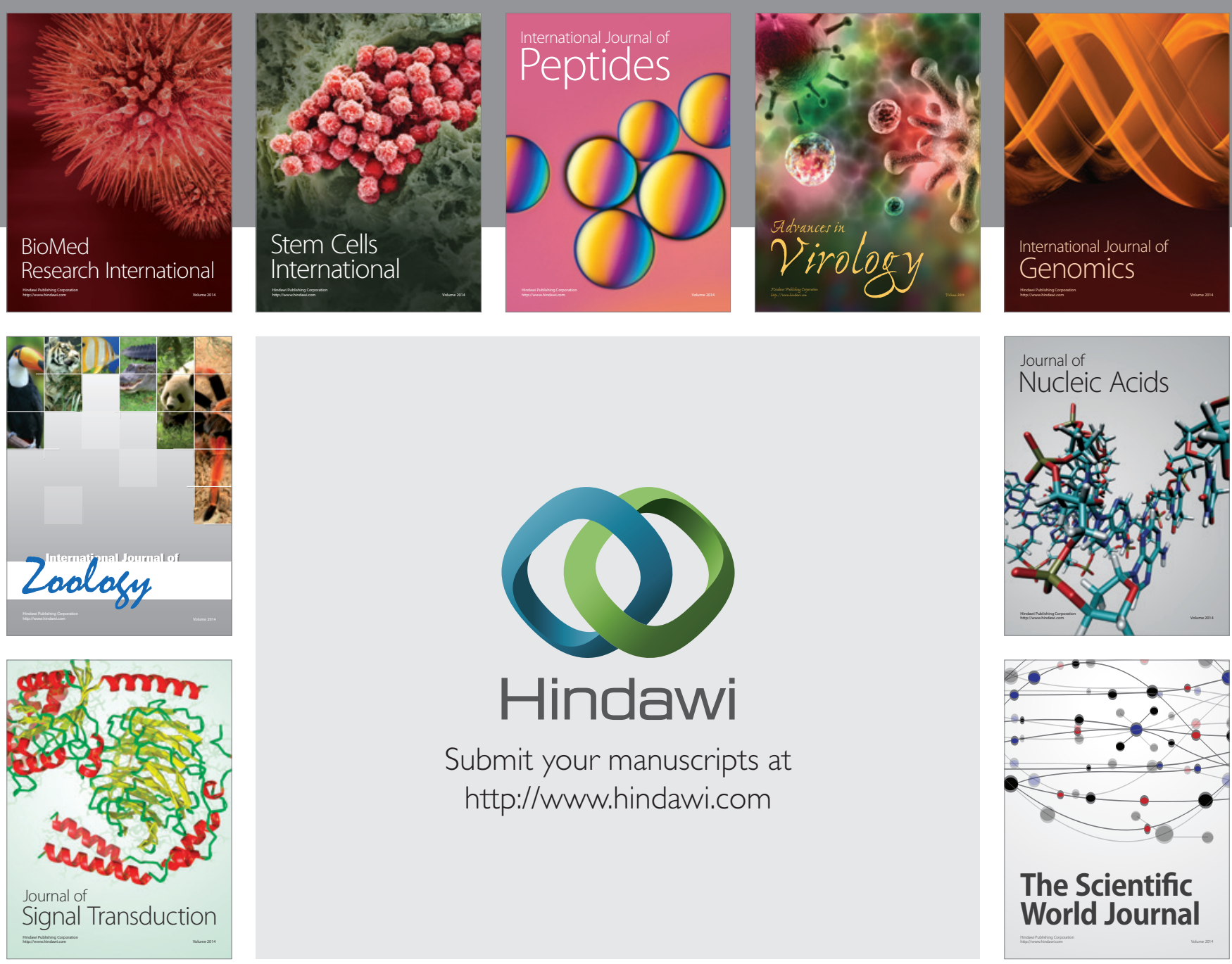

Submit your manuscripts at

http://www.hindawi.com
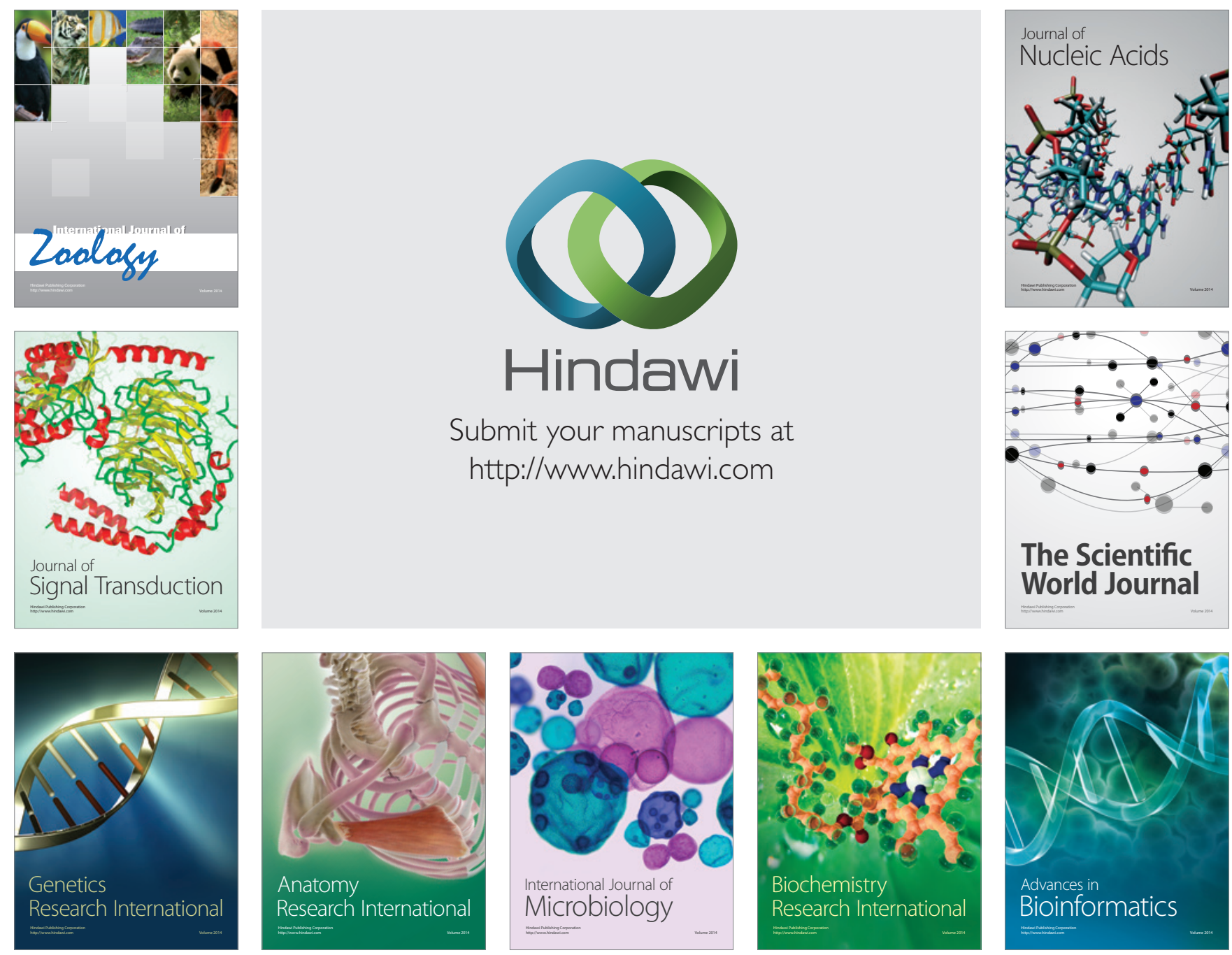

The Scientific World Journal
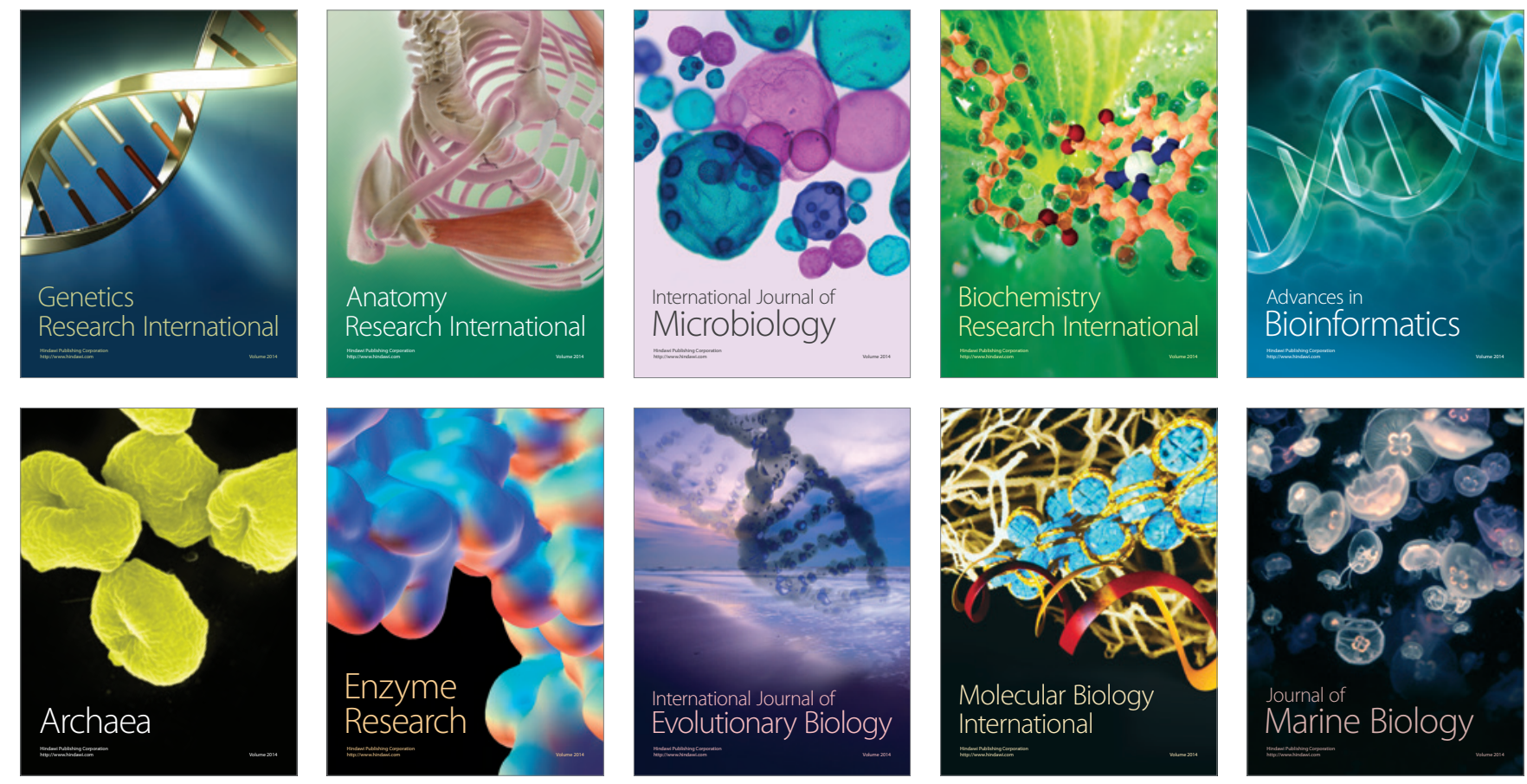